\title{
Two-step Homogenization of Poroelastic Properties of a Limestone
}

\author{
Trieu HUNG TRUONG ${ }^{1 *}$, Nguyen NGOC BIEN ${ }^{1)}$, Pham DUC THO ${ }^{1)}$, \\ Vu MINH NGOC ${ }^{3)}$, Do NGOC ANH ${ }^{1)}$ Nguyen SY TUAN ${ }^{3)}$, \\ Tran NAM HUNG ${ }^{4)}$, Nguyen THI THU NGA ${ }^{4)}$
}

\footnotetext{
1) Hanoi University of Mining and Geology, Hanoi, Vietnam, Vietnam; email: trieuhungtruong@humg.edu.vn; nguyenngocbien@humg. edu.vn; phamductho@humg.edu.vn; dongocanh@humg.edu.vn

2) Institute for Computational Science, Ton Duc Thang University, Ho Chi Minh City, Vietnam; email: vuminhngoc@tdtu.edu.vn

3) Institute of Research and Development, Duy Tan University, Da Nang, Viet Nam; email: stuan.nguyen@gmail.com

${ }^{4)}$ Le Quy Don Technical University, Institute of Techniques for Special Engineering, Hanoi, Vietnam; email: nguyennga@lqdtu.edu.vn
}

\section{http://doi.org/10.29227/IM-2020-02-06}

Submission date: 06-03-2020 | Review date: 22-09-2020

\section{Abstract}

This study aims at deriving the effective poroelastic properties of the oolitic limestones based on the Hashin composite sphere assemblage (CSA) micromechanical theory. The microstructure of oolitic limestones generally exhibits an assemblage of grains (oolites) surrounded by a matrix. Grain and matrix are linked via the interfacial transition zone (ITZ). Pores exist in these three material phases (oolite, ITZ and matrix). A two-step homogenization method is proposed. The first step consists of upscaling the properties of each porous phase (i.e. porous oolite, porous ITZ and porous matrix) in which each phase contains two sub-phases including pore and solid. The differential self-consistent scheme is used for the first step. At the second step, the three different porous constituents (oolite, ITZ and matrix) are assembled in a CSA model. A mathematical analogy between thermoelasticity and poroelasticity is used to obtain the effective poroelastic properties. A comparison between the proposed model and test data on the oolitic limestone from Bourgogne (France) helps to calibrate the model parameters and to highlight the role of ITZ phase.

Keywords: oolitic limestone; tow-step homogenization; CSA; poro-elastic properties; differential self-consistent

\section{Introduction}

Knowledge of the poroelastic properties (drained and undrained bulk and shear moduli; Biot coefficient; Biot modulus; Skempton's coefficient, etc.) is significant for numerous environmental and industrial engineering problem. Indeed, thermo-poroelastic approach is usually considered for the design of geological sequestration of CO2 (Seyedi et al., 2011, 2015); nuclear waste disposal ( $\mathrm{Vu}$ et al., 2019; Conil et al., 2020; Seyedi et al., 2017.); petroleum reservoir engineering (Trieu, 2010, 2011); geothermal energy production (Han et al., 2019); groundwater (Kim, 2004); etc. The fully coupling between mechanical and hydraulic phenomena is performed based on the fundamental theory of Biot (Biot, 1941; Coussy, 2004), which considered a saturated porous medium as a superposition of two continua: skeleton and pore fluid. The poroelastic behaviour of the porous media is described by four state variables: total stress tensor; strain tensor of the skeleton; pore pressure and the fluid mass variation. Main parameters of the poroelasticity are bulk and shear moduli and Biot coefficient, in which Biot coefficient is the key parameter of hydromechanical coupling. Indeed, the Biot coefficient appears in the effective stress equation and the fluid mass balance equation (Coussy, 2004).

Porous carbonate rocks are the host formation of numerous petroleum reservoir around the world (Xu \& Payne, 2009). Therefore, determination and prediction of physical properties of carbonate rocks are paramount in geophysics and geomechanics. Field measurement (e.g. log well technique) allows measuring the elastic properties (compres- sional and shear ultrasonic wave velocities) of the host rock (Nguyen et al., 2015, 2017). However, laboratory test on the sample, including drained, undrained, pore pressure loading and unjacketed tests, must be had recourse to determine the complete poroelastic properties (Lion et al., 2004). Some properties can be measured directly or indirectly from a laboratory test (Lion et al., 2004). Besides, theoretical and numerical methods such as micromechanical approach (Dormieux et al., 2006; Giraud et al., 2012; Levin \& Alvarez-Tostado, 2006; Nguyen et al., 2017) or machine learning (Madhubabu et al., 2016) have been widely used to predict and extrapolate the poroelastic properties of carbonate rock from measured data.

This study aims at proposing a theoretical model based on two-steps homogenization of poroelastic properties of a limestone from Bourgogne (France) (Lion et al., 2004). This limestone belongs to the oolitic rocks. Microstructure observation evidence that the limestone is a formation of concentric ooids (oolitic grain) nearly spherical coated by a thin layer with high porosity and then a matrix. The oolite consists of micrite and pore, while the surrounding matrix is constituted by cementitious sparite and pore. Many studies in the literature on various limestones have shown similar microstructure (Chen et al., 2017; Fabre \& Gustkiewicz, 1997; Grgic, D, 2011; Hart \& Wang, 1995). The composite sphere assemblage (CSA) models proposed by Hashin (Hashin, 1962) is quite suitable for this microstructure of limestone. Moreover, CSA model is also appropriated for materials containing intermediate and large volume fractions of grains when estimating their poroelastic properties. Whereas, the matrix-inclusion meth- 


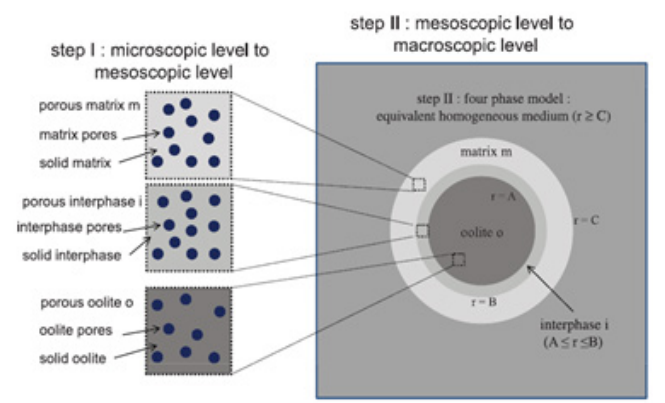

Fig. 1. Two-step micro-meso and meso-macro upscaling model for the oolitic rock (three phases of composite sphere assemblage: ooid (o); ITZ (i) and matrix (m)) Rys. 1. Dwuetapowy model zwiększenia mikro-mezo i mezo-makro dla skały oolitycznej (trzy fazy komplesowego zbióru ooid (o); ITZ (i) i macierz (m))

od based on Eshelby solution (Eshelby, 1957) coupling with a homogenization scheme (e.g. Non-interaction (Shafiro et al., 2000); Mori-Tanaka (Mori \& Tanaka, 1973); Differential (Norris, 1985; Nemat-Nasser \& Hori, 1999); Self-consistent (Hill, 1965; Nguyen et al., 2020; Vu, 2012, 2018); Differential Self-consistent (Norris, 1985; Zimmerman, 1996); Iterative Self-consistent (Zouari et al., 2008); Adaptative (Nguyen et al., 2016, 2019, 2020), Hashin et Strickman borns (Hashin \& Shtrikman, 1962, 1963), etc.) is proper for the low and moderate volume fraction of grains.

In the framework of CSA model, oolitic limestone is considered as a four-phase model including concentric phases: porous ooid; porous matrix and thin porous layer representing the interphase or interfacial transition zone (ITZ) between grain and matrix. ITZ exhibits as a weakness zone, where the porosity is normally much higher, and the stiffness is lower than the oolitic grains and the cementation sparite matrix. The role of the interphase of the rock-composite material is similar to the interface (ITZ) between aggregate and cement matrix in concrete material (Pham et al., 2020; Nguyen et al., 2016, 2019). Two-steps upscaling is proposed to derive the closed-form solution of poroelastic properties of the oolitic limestone. At the first step, the properties of three phases: oolities (micropore and micrite solid); ITZ (micropore and skeleton solid) and surrounding matrix (micropore and sparite solid) are determined based on the differential self-consistent scheme. At the second step, oolites, ITZ and embedding matrix are homogenized in the framework of Hashin four-phase CSA models, in which, ooid is assumed to be spherical while ITZ and matrix are represented by spherical shells. The case without ITZ is also considered to show the role of ITZ when deriving the poroelastic properties of the oolitic rock. Threephase CSA model in the latter case is the well-known generalized self-consistent scheme. The derivation of the poroelastic properties of porous rock is based on the correspondence between the linear poroelasticity and the linear thermoelasticity (Berryman, 1997; Berryman \& Milton, 1991, 1992; Levin \& Alvarez-Tostado, 2003). Properties of each constituent at the first step of homogenization are taken from the literature. Comparison with the measurement of the limestone from Bourgogne (France) shows the accuracy of the proposed homogenization-based model.

\section{A two-step homogenization model}

Two-step homogenization model (micro-meso and meso-macro) is proposed to derive the overall poroelastic properties of the oolitic limestone, which is considered as a concentric spherical assemblage of three phases: ooids, interphase (ITZ) and cementitious matrix. Each phase is constituted by pore and calcite mineral (micrite for ooids and ITZ and sparite for matrix). In the following, pore and calcite (micrite, sparite) are referred to the microscale. Ooid, ITZ and cementation matrix are designated the mesoscale. A representative elementary volume (REV) of limestone is envisaged as the macroscale. The first upscaling from the microscopic to the mesoscopic scales (step I) is performed based on the differential self-consistent scheme (Norris, 1985; Zimmerman, 1996). The step II is the second upscaling from the mesoscopic to macroscopic scale, which is carried out by the CSA four-phase model (Hashin \& Monteiro, 2002). Fig. 1 shows the schematically principle of the two-step upscaling to derive the poroelastic properties of the limestone.

We consider a REV $\Omega$ of limestone constituted by three phases oolities (o) with volume $\Omega$ o, interphase (i) with volume $\Omega \mathrm{i}$ and surrounding matrix $(\mathrm{m})$ with volume $\Omega \mathrm{m}$. The volume fraction of these three phases are defined by

$f_{o}=\frac{\Omega_{o}}{\Omega}, f_{i}=\frac{\Omega_{i}}{\Omega}, f_{m}=\frac{\Omega_{m}}{\Omega}, f_{o}+f_{i}+f_{m}=1$

The total porosity $\Omega \mathrm{p}$ is decomposed into three parts at the microscale: ooid porosity $\Omega$ op; interphase porosity $\Omega$ ip and matrix porosity $\Omega \mathrm{mp}$. We define

$f_{o p}=\frac{\Omega_{p p}}{\Omega}, f_{i p}=\frac{\Omega_{p}}{\Omega}, f_{n p}=\frac{\Omega_{n p}}{\Omega}, f_{p}=\frac{\Omega_{p}}{\Omega}=f_{o p}+f_{i p}+f_{n p}$

At the first step one defines the ooid, ITZ and matrix porosities as:

$f_{j p}^{I}=\frac{\Omega_{j p}}{\Omega_{j}}=\frac{f_{j p}}{f_{j}}(\mathrm{j}=\mathrm{o}, \mathrm{i}, \mathrm{m})$

At the microscopic scale, the skeleton solid of three constituents $(\mathrm{o}, \mathrm{i}, \mathrm{m})$ is assumed to be isotropic. The elastic stiffness and compliance fourth-order tensors $\mathrm{C}_{\mathrm{j}}$ and $\mathrm{S}_{\mathrm{j}}$ are

$\mathbb{C}_{j}=3 k_{j} \mathrm{~J}+2 \mu \mathbb{K}, \quad \mathbb{S}_{j}=\frac{1}{3 k_{j}} \mathrm{~J}+\frac{1}{2 \mu_{j}} \mathbb{K}$

where $\mathrm{kj}$ and $\mu \mathrm{j}$ are the bulk and shear moduli of the constituent $j(j=o, i, m)$. $r$, J and $E$ refer to the fourth-order symmetric identity tensor, spherical and deviatoric tensors, i.e.

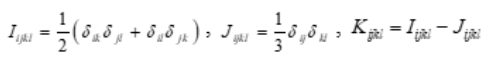

$\left(\delta_{\mathrm{ij}}\right.$ is the Kronecker delta). 
Tab. 1. Input parameters for two-step homogenization mode

Tab. 1. Parametry wejściowe dla dwuetapowego trybu homogenizacji

\begin{tabular}{|l|l|l|l|}
\hline Parameters & Ooid $(\mathrm{o})$ & Interphase $(\mathrm{i})$ & Matrix $(\mathrm{m})$ \\
\hline$k(\mathrm{GPa})$ & 76 & 1.52 & 76 \\
\hline$\mu(\mathrm{GPa})$ & 36.8 & 0.736 & 36.8 \\
\hline volume fraction $f j(j=0, \mathrm{i}, \mathrm{m})$ & 0.70 & 0.015 & 0.285 \\
\hline Porosity $f j p(j=0, \mathrm{i}, \mathrm{m})$ & 0.119 & 0.010 & 0.070 \\
\hline
\end{tabular}

Tab. 2. Macroscopic poroelastic properties of the studied limestone

Tab. 2. Makroskopowe właściwości poroelastyczne badanego wapienia

\begin{tabular}{|l|l|l|l|}
\hline Properties & Measure & Model without ITZ & Model with ITZ \\
\hline Total porosity $\phi$ & 0.199 & 0.199 & 0.199 \\
\hline Young's modulus E $(\mathrm{GPa})$ & 24.6 & 61.73 & 24.5 \\
\hline Poisson ratio & & 0.27 & 0.22 \\
\hline Solide phase modulus $\mathrm{k}_{\mathrm{s}}(\mathrm{GPa})$ & 63.23 & 76 & 53.38 \\
\hline Drained modulus $\mathrm{k}_{\mathrm{d}}(\mathrm{GPa})$ & 14.65 & 43.83 & 14.49 \\
\hline Shear modulus $(\mathrm{GPa})$ & 15.77 & 23.90 & 10.07 \\
\hline Biot coefficient b & 0.77 & 0.42 & 0.76 \\
\hline Solid Biot modulus M $(\mathrm{GPa})$ & 9.214 & 9.7656 & 9.208 \\
\hline
\end{tabular}

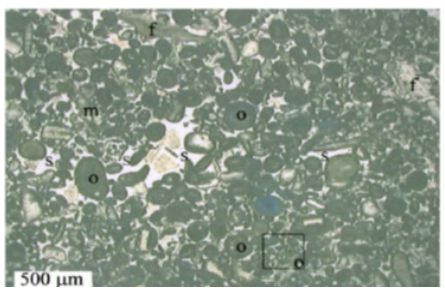

Fig. 2. Micro-petrographic observation of the Bourgogne limestone (Lion et al., 2004)

Rys. 2. Obserwacja mikropetrograficzna wapienia z Bourgogne (Lion i in., 2004)

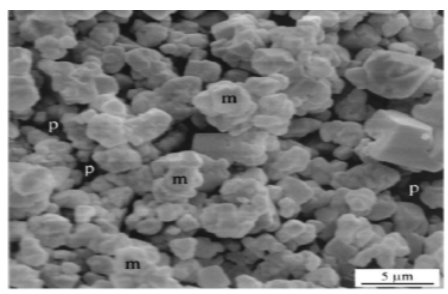

Fig. 3. Microstructure of an ooid constituted by micrite crystals and fine porosity (Lion et al., 2004)

Rys. 3. Mikrostruktura ooidu ustawiona z kryształów mikrytowych i drobnej porowatości (Lion i in., 2004)

\section{Micro-meso transition (step I)}

The first step of micro-macro upscaling results in the overall poroelastic properties of three constituents including porous oolite; porous matrix and porous interphase. Each constituent is composed of pore and skeleton solid. As shown by (Nguyen et al., 2011), differential self-consistent scheme seems to be the most appropriated for two-step homogenization models for poroelasticity, which is thus adopted in this study.

Effective linear poroelastic constitutive equations at the mesoscale, with the assumption of zero initial stress and zero initial pore pressure, are written as follows ( Dormieux et al., 2006).

$$
\begin{aligned}
& \underline{\underline{\Sigma}}=\mathbb{C}_{j}^{\prime}: \underline{\underline{E}}-\underline{\underline{B}}_{j}^{\prime} P \\
& \phi-\phi_{o}=\underline{\underline{B}}_{j}^{\prime}: \underline{\underline{E}}+\frac{P}{N_{j}^{\prime}}
\end{aligned}
$$

where $\Sigma$, E represents the mesoscopic stress and strain tensor; $\phi$ the porosity; $\mathrm{P}$ the pore pressure; $\mathrm{B}_{\mathrm{j}}^{\mathrm{I}}$ the Biot tensor coefficient and $\mathrm{N}_{\mathrm{j}}^{\mathrm{I}}$ the solid Biot modulus $(\mathrm{j}=\mathrm{o}, \mathrm{i}, \mathrm{m})$.

Micro-macro compatibility condition yields:

$$
\underline{B}_{j}^{I}=i:\left(\mathbb{I}-\mathbb{S}_{j}: \mathbb{C}_{j}^{I}\right), \frac{1}{N_{j}^{I}}=\left(\underline{\underline{B}}_{j}^{I}-f_{j p}^{I} i\right): \mathbb{S}_{j}: i
$$

in which, is the second-order identify tensor.

For the particular case where both solid constituent $j$ and solid skeleton are isotropic and homogeneous, we have

$$
\begin{aligned}
& \underline{\underline{\underline{\Sigma}}}=\left(3 k^{\prime}, \mathrm{J}+2 \mu_{j}^{\prime} \mathbb{Z}\right): \underline{\underline{\underline{E}}}-b_{j}^{\prime} P_{i} \\
& \phi-\phi_{0}=b_{j}^{\prime} t: \underline{\underline{E}}+\frac{P}{N_{j}^{\prime}} \\
& \underline{\underline{B}}_{j}^{i}=b_{j}^{I_{i}}, b_{j}^{\prime}=1-\frac{k_{j}^{\prime}}{k_{j}}, \frac{1}{N_{j}^{\prime}}=\frac{b_{j}^{\prime}-f_{i}^{\prime}}{k_{j}}
\end{aligned}
$$

Assuming the solid phase and pore take the spherical shape at the microscopic scale, differential self-consistent approach gives an estimation of elastic properties such as (Norris, 1985; Zimmerman, 1996)

$$
\begin{aligned}
& \frac{\mu_{j}^{D S C}}{\mu}=\left(1-f_{j p}^{l}\right)^{2}\left(\frac{1+\kappa_{j}\left(\mu_{j}^{D S C} / \mu_{j}\right)^{3 / 3}}{1+\kappa_{j}}\right)^{1 / 3} \\
& \frac{k_{j}^{D S C}}{k_{j}}=\frac{\mu_{j}^{D S C}}{\mu_{j}}\left(\frac{1+2 \kappa_{j}}{1+2 \kappa_{j}\left(\mu_{j}^{D C} / \mu_{j}\right)^{3 / 5}}\right)
\end{aligned}
$$




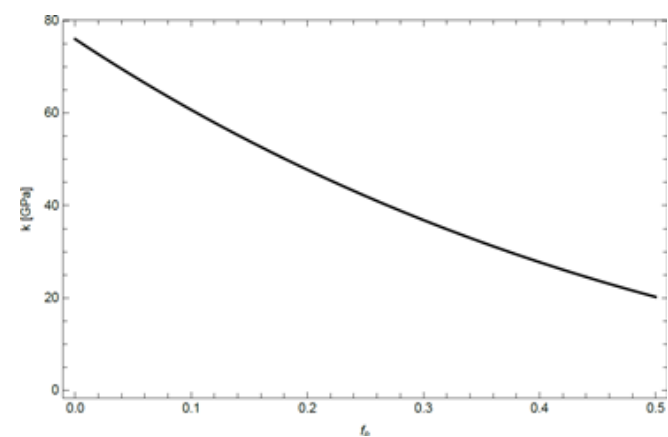

Fig. 4. Variation of bulk modulus of ooid and cement matrix versus their porosity (step I) Rys. 4 Zmiana modułu objętościowego ooidu i matryce cementowe w zależności od ich porowatości (etap I)

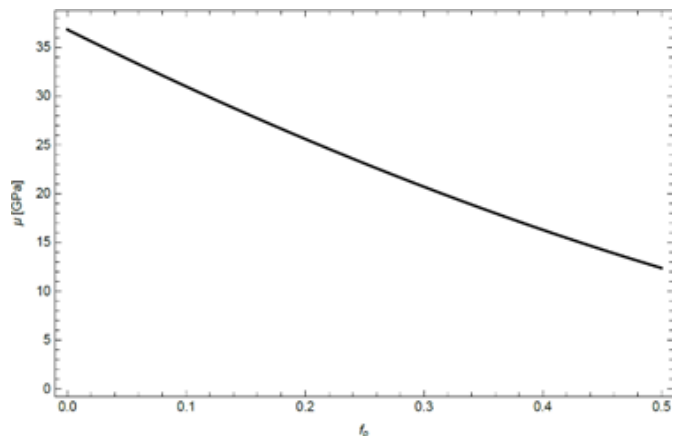

Fig. 5. Variation of shear modulus of ooid and cement matrix versus their porosity (step I) Rys. 5. Zmiana modułu ścinania ooidu i matryce cementowe w zależności od ich porowatości (etap I)

in which,

$$
\kappa_{j}=\frac{1-5 v_{j}}{2\left(1+v_{j}\right)}=-\frac{3 k_{j}-4 \mu_{j}}{6 k_{j}}
$$

Therefore, the mesoscopic bulk and shear moduli are the root of the nonlinear equations 10. The Biot coefficient and Biot modulus are determined from the equation 8 .

$$
\begin{aligned}
& b_{j}=\frac{f_{p p}^{\prime}}{1-\alpha_{j}\left(1-f_{j p}^{\prime}\right)}, \frac{1}{N_{j}}=\frac{\alpha_{j}\left(1-f_{j p}^{I}\right) f_{j p}^{I}}{k_{j}\left(1-\alpha_{j}\left(1-f_{j p}^{I}\right)\right)} \\
& \alpha_{j}=\frac{3 k_{j}}{3 k_{j}+4 \mu_{j}}, \beta_{j}=\frac{2\left(k_{j}+2 \mu_{j}\right)}{5\left(3 k_{j}+4 \mu_{j}\right)}
\end{aligned}
$$

Once the mesoscopic poroelastic properties are formed by equations 10,11, and 12, they are introduced in the next step (step II) to determine the overall properties of the limestone based on the CSA model (four-phase model).

\section{Meso-macro transition (step II)}

The second step (step II) consists in the upscaling from the mesoscale (i.e. oolite, ITZ and matrix) to the macroscale (limestone) by using the three-phase composite sphere model (or four-phase model). The homogenized linear poroelastic constitutive equation reads

$$
\begin{aligned}
& \underline{\underline{\Sigma}}=\mathbb{C}_{\text {boen }}^{\prime l}: \underline{\underline{E}}-\underline{\underline{B}}_{\text {bon }}^{\| l} P \\
& \phi-\phi_{o}=\underline{\underline{B}}_{\mathrm{bom}}^{\| I}: \underline{\underline{E}}+\frac{P}{N_{\mathrm{bom}}^{I I}}
\end{aligned}
$$

where $\mathrm{C}_{\text {hom }}^{\mathrm{II}}$, $\mathrm{B}_{\text {hom }}^{\mathrm{II}}$ and $\mathrm{N}_{\text {hom }}$ II denote the fourth-order effective macroscopic stiffness tensor; the second-order Biot coefficient tensor and the solid Biot modulus.

It is worth to notice that the constitutive equations of linear poroelasticity and those of linear thermoelasticity are similar (Berryman, 1997; Berryman \& Milton, 1991, 1992; Levin \& Alvarez-Tostado, 2003). Therefore, the poroelastic properties of three-phase CSA (or four-phase model) can be obtained from the known results of such a model in the framework of the thermoelastic theory (He \& Benveniste, 2004; Herve, 2002; Herve \& Zaoui, 1993). Hereafter, the final solution of poroelastic properties of limestone in step II is shown. Detailed development resulting in these results were presented in (Nguyen, 2010).

The bulk modulus:

$$
k_{\text {mom }}^{\prime \prime \prime}=k_{m}-\frac{3 k_{m}+4 \mu_{m}}{3-\frac{f_{o} \omega_{1}+f_{i} \omega_{2}}{\left(f_{o}+f_{i}\right)\left(f_{o} \omega_{3}+f_{i} \omega_{4}\right)}}
$$

where:

$$
\begin{array}{ll}
\omega_{1}=\frac{3 k_{o}+4 \mu_{m}}{3 k_{0}+4 \mu_{i}} \quad, \quad \omega_{2}=\frac{3 k_{i}+4 \mu_{m}}{3 k_{i}+4 \mu_{i}} \\
\omega_{3}=\frac{k_{o}-k_{m}}{3 k_{0}+4 \mu_{i}} \quad, \quad \omega_{4}=\frac{3 k_{i}-k_{m}}{3 k_{i}+4 \mu_{i}}
\end{array}
$$

and the Biot coefficient:

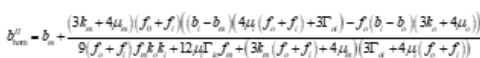

With:

$$
\begin{aligned}
& f_{m}=1-f_{o}-f_{i} \\
& \Gamma_{o i}=f_{o} k_{i}+f_{i} k_{o} \\
& \Gamma_{i o}=f_{o} k_{o}+f_{1} k_{1}
\end{aligned}
$$

and the Biot modulus:

$\frac{1}{N_{\mathrm{hm}}^{I I}}=\sum_{i=1}^{3} f_{i} \frac{1}{N_{i}}+\frac{N N_{\mathrm{hm}}}{D N_{\mathrm{hms}}}$ 


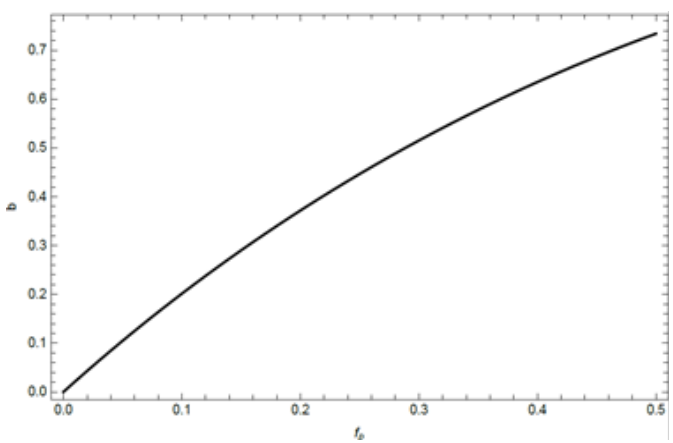

Fig. 6. Variation of Biot coefficient of ooid and cement matrix versus their porosity (step I)

Rys. 6. Zmienność współczynnika Biot'a matrycy ooidalu i matrycy cementowe w zależności od ich porowatości (etap I)

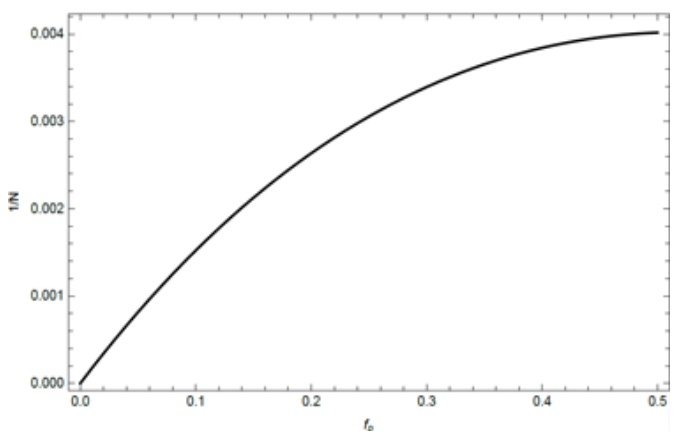

Fig. 7. Variation of $1 / \mathrm{N}$ of ooid and cement matrix versus their porosity (step I)

Rys. 7. Zmiana 1/N ooidu i matryce cementowe w zależności od ich porowatości (etap I)

\section{In which:}

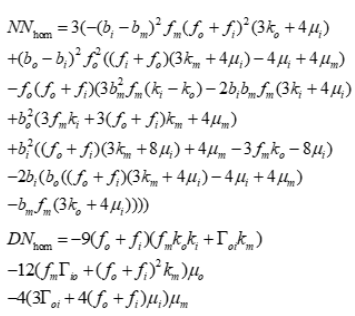

In the case without the interphase becomes the wellknown two-phase CSA model (the assemblage of oolitic grain coated by matrix). The solution of such case is obtained by taking $\mathrm{f}_{\mathrm{i}}=0$ in equations from 14 to 19 .

$$
\begin{aligned}
& k_{\text {mom }}^{\prime \prime}=k_{m i}^{\prime}+\frac{\left(3 k_{m}^{\prime}+4 \mu_{m}^{\prime}\right)\left(k_{o}^{\prime}-k_{m}^{\prime}\right) f_{o}}{4 \mu_{m}^{\prime}+3 k_{o}^{t} f_{m}+3 k_{m}^{\prime} f_{o}} \\
& b_{\text {iom }}^{\prime \prime}=b_{m}^{\prime}+\frac{\left(3 k_{m}^{\prime}+4 \mu_{m}^{\prime}\right)\left(b_{o}^{\prime}-b_{m}^{\prime}\right) f_{o}}{4 \mu_{m}^{\prime}+3 k_{o}^{\prime} f_{m}+3 k_{m}^{\prime} f_{o}} \\
& \frac{1}{N_{\mathrm{mam}}^{I I}}=\frac{f_{o}}{N_{o}^{I}}+\frac{1-f_{o}}{N_{m}^{I}}+\frac{3\left(b_{m}^{I}-b_{o}^{I}\right)^{2}\left(1-f_{o}\right) f_{o}}{3 f_{o}\left(k_{m}^{I}-k_{o}^{I}\right)+3 k_{o}^{l}+4 \mu l_{m}^{I}}
\end{aligned}
$$

The effective Biot modulus obtained by the following relation:

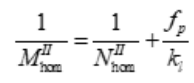

Hashin (Hashin, 1962) considered only two layers and obtained an identical formulation for bulk modulus as the solutions ......

\section{Application of the present model to limestone from Bourgogne (France)}

\subsection{Studied oolitic rock}

The material studied in this work is an oolitic limestone extracted from Bierry-les-Belles-Fontaines, in Bourgogne (France). Different observation techniques including X-ray diffraction (XRD), optical microscopy (OM) and scanning electron microscopy coupled with an energy dispersive spectrometer (SEM-EDS) were used for petrographic study. Microstructure characterization evidenced that the limestone is an assemblage of ooids of size 100-1000 $\mu$ m made of concentric spheres of calcite (Fig. 2). Sparite (coarse crystalline calcite) and minor micrite (micro-crystalline calcite with a grain size finer than $4 \mu \mathrm{m}$ ) are present in the cement matrix. SEM photomicrograph shows that an ooid is constituted by micrite crystals and microporosity (Fig. 3). At a centimetric scale, the rock can be considered as homogeneous. Both sparite and micrite are made of $100 \% \mathrm{CaCO}_{3}$.

Poro-elastic properties of the considered rock were characterized by an experimental device enabling confining pressure ( $\leq 60 \mathrm{MPa})$ to be applied, injected or expelled fluid mass and strains to be recorded. The main poroelastic properties can be determined either by direct or indirect measurement. Drained bulk modulus kd is measured by keeping a constant pore pressure (drained condition $\Delta \mathrm{P}_{\mathrm{f}}=0$ ) when increasing the isotropic confining pressure. Thus, the drained bulk modulus is the ratio between the variation in confining pressure $\Delta \mathrm{P}_{c}$ and the variation in volumetric strain $\Delta \varepsilon v$. Undrained bulk modulus ku and Skempton's coefficient B are measured when increasing the confining pressure on the saturated sample under undrained condition. $\mathrm{B}$ is the ratio between the variation in pore pressure $\Delta \mathrm{P}_{\mathrm{f}}$ and $\Delta \mathrm{P}_{\mathrm{c}} \cdot \mathrm{k}_{\mathrm{u}}$ is the ratio between $\Delta \mathrm{P}_{\mathrm{c}}$ and $\Delta \varepsilon v$. The matrix bulk modulus ks is determined when controlling $\Delta \mathrm{P}_{\mathrm{f}}=\Delta \mathrm{P}_{\mathrm{c}}$ and $\mathrm{k}_{\mathrm{s}}$ is the ratio between $\Delta \mathrm{P}_{\mathrm{c}}$ and $\Delta \varepsilon v$. $\mathrm{k}_{\mathrm{d}}$, 
$\mathrm{k}_{\mathrm{s}}$ and porosity $\phi$ are known, the Biot coefficient $\mathrm{b}$ and the Biot modulus $\mathrm{M}$ can be determined indirectly from equations 9 and 23. Besides, these two poroelastic parameters can also be measured directly by the experimental device. To measure Biot coefficient $b$, a fluid injection into the sample under the drained condition when keeping a constant confining stress $\left(\Delta \mathrm{P}_{\mathrm{c}}=0\right)$ was performed. We obtain $\mathrm{b}=\mathrm{k}_{\mathrm{d}} \times \Delta \varepsilon \mathrm{v} \cdot / \Delta \mathrm{P}_{\mathrm{f}^{\prime}}$ On the contrary, $\mathrm{M}$ can be measured from an undrained hydrostatic test. A recording of pore pressure variation yields $\mathrm{M}=$ $-(1 / b) \times \Delta \mathrm{P}_{\mathrm{f}} / \Delta \varepsilon v$. Details about the measurement and test data were presented by (Lion et al., 2004).

\subsection{Comparison between the proposed model and test data}

The parameters of the two-step homogenization models include the bulk and shear modulus of micrite and sparite (kmi, $\mu \mathrm{mi}, \mathrm{ksp}, \mu \mathrm{sp}$ ); porosity of three phases fpo, fpi, fpm and the volume fractions of oolites, The elastic properties of micrite and sparite were deduced from microidentation tests on Lavoux limestone (France)(Giraud et al., 2012). Moreover the repartition of porosity within that limestone at the mesoscale was also given by Giraud (Giraud et al., 2012). These known parameters from Lavoux limestone is adopted in this study for Bourgogne limestone (Table 1). Fig. 4 to Fig. 7 show the poroelastic properties of porous ooid and porous matrix as a function of their porosity, which are resulted from the step I. The results of step II of the proposed model are given in Table 2 for two cases with and without ITZ. Comparison of model results to the test data of (Lion et al., 2004) shows that the four-phase model is quite appropriated to predict the poroelastic properites of oolitic limestone. Moreover, this comparison also evidences the role of ITZ in the prediction.

\section{Conclusion}

This paper presents an analytical model to predict the poroelastic of oolitic rock. The studied material appears as an assemblage of three layers including spherical oolitic grain coated by double spherical shells mince interphase and cement matrix. Ooid and interphase are made by micrite (micro-crystalline calcite) and micropores, while cement matrix is constituted by sparite (coarse crystalline calcite) and micropores. Based on the petrographic characterization of this rock, a two-step homogenization model is proposed. The step I consists of the micro-meso upscaling, which homogenize the properties of ooid, ITZ and matrix based on the differential self-consistent scheme. The step II adopts the three phase composite sphere model (four-phase model) to obtain the overall poroelastic of the rock. The derivation process is based on the correspondence between constitutive equations of poroelasticity and those of thermoelasticity. The validation of the proposed model is shown by the comparison between test data. The comparison between three-phase model (without ITZ) and four-phase model shows the significant role of the interphase.

\section{Acknowledgement}

This work is financially supported by the Ministry of Education and Training of Vietnam, Grant No. B2019MĐA-562-18. 


\section{Literatura - References}

1. Berryman, J. G. (1997). Generalization of Eshelby's Formula for a Single Ellipsoidal Elastic Inclusion to Poroelasticity and Thermoelasticity. Physical Review Letters, 79(6), 1142-1145. https://doi.org/10.1103/PhysRevLett.79.1142.

2. Berryman, J. G., \& Milton, G. W. (1991). Exact results for generalized Gassmann's equations in composite porous media with two constituents. GEOPHYSICS, 56(12), 1950-1960. https://doi.org/10.1190/1.1443006.

3. Berryman, J. G., \& Milton, G. W. (1992). Exact results in linear thermomechanics of fluid-saturated porous media. Applied Physics Letters, 61(17), 2030-2032. https://doi.org/10.1063/1.108349

4. Biot, M. A. (1941). General Theory of Three-Dimensional Consolidation. Journal of Applied Physics, 12(2), 155-164. https://doi.org/10.1063/1.1712886.

5. Chen, F., Giraud, A., Grgic, D., \& Kalo, K. (2017). A composite sphere assemblage model for porous oolitic rocks: Application to thermal conductivity. Journal of Rock Mechanics and Geotechnical Engineering, 9(1), 54-61. https:// doi.org/10.1016/j.jrmge.2016.06.012.

6. Conil, N., Vitel, M., Plua, C., Vu, M. N., Seyedi, D., \& Armand, G. (2020). In Situ Investigation of the THM Behavior of the Callovo-Oxfordian Claystone. Rock Mechanics and Rock Engineering. https://doi.org/10.1007/s00603-020-02073-8.

7. Dormieux, L, Kondo, D, \& Ulm, F. (2006). Microporomechanics. John Wiley and Sons. https://www.amazon.com/ Microporomechanics-Luc-Dormieux/dp/0470031883

8. Eshelby, J. D., \& Peierls, R. E. (1957). The determination of the elastic field of an ellipsoidal inclusion, and related problems. Proceedings of the Royal Society of London. Series A. Mathematical and Physical Sciences, 241(1226), 376-396. https://doi.org/10.1098/rspa.1957.0133.

9. Fabre, D., \& Gustkiewicz, J. (1997). Poroelastic properties of limestones and sandstones under hydrostatic conditions. International Journal of Rock Mechanics and Mining Sciences, 34(1), 127-134. https://doi.org/10.1016/ S1365-1609(97)80038-X.

10. Giraud, A., Hoxha, D., Do, D. P., \& Magnenet, V. (2008). Effect of pore shape on effective porothermoelastic properties of isotropic rocks. International Journal of Solids and Structures, 45(1), 1-23. https://doi.org/10.1016/j. ijsolstr.2007.07.005.

11. Giraud, A., Nguyen, N. B., \& Grgic, D. (2012). Effective poroelastic coefficients of isotropic oolitic rocks with micro and meso porosities. International Journal of Engineering Science, 58, 57-77. https://doi.org/10.1016/j.ijengsci.2012.03.025.

12. Grgic, D. (2011). Influence of $\mathrm{CO} 2$ on the long-term chemomechanical behavior of an oolitic limestone-Grgic-2011-Journal of Geophysical Research: Solid Earth-Wiley Online Library. Journal of Geophysical Research, 116. https://agupubs.onlinelibrary.wiley.com/doi/full/10.1029/2010JB008176

13. Han, S., Cheng, Y., Gao, Q., Yan, C., Han, Z., \& Zhang, J. (2019). Investigation on heat extraction characteristics in randomly fractured geothermal reservoirs considering thermo-poroelastic effects. Energy Science \& Engineering, 7(5), 1705-1726. https://doi.org/10.1002/ese3.386

14. Hart, D. J., \& Wang, H. F. (1995). Laboratory measurements of a complete set of poroelastic moduli for Berea sandstone and Indiana limestone. Journal of Geophysical Research: Solid Earth, 100(B9), 17741-17751. https://doi. org/10.1029/95JB01242

15. Hashin, Z., \& Monteiro, P. J. M. (2002). An inverse method to determine the elastic properties of the interphase between the aggregate and the cement paste. Cement and Concrete Research, 32(8), 1291-1300. https://doi. org/10.1016/S0008-8846(02)00792-5

16. Hashin, Z. (1962). The Elastic Moduli of Heterogeneous Materials. Journal of Applied Mechanics, 29(1), 143-150. https://doi.org/10.1115/1.3636446

17. He, Q.-C., \& Benveniste, Y. (2004). Exactly solvable spherically anisotropic thermoelastic microstructures. Journal of the Mechanics and Physics of Solids, 52(11), 2661-2682. https://doi.org/10.1016/j.jmps.2004.03.012

18. Herve, E. (2002). Thermal and thermoelastic behaviour of multiply coated inclusion-reinforced composites. International Journal of Solids and Structures, 39(4), 1041-1058. https://doi.org/10.1016/S0020-7683(01)00257-

19. Herve, Eveline, \& Zaoui, A. (1993). N-Layered inclusion-based micromechanical modelling. International Journal of Engineering Science, 31(1), 1-10. https://doi.org/10.1016/0020-7225(93)90059-4

20. Hill, R. (1965). A self-consistent mechanics of composite materials. Journal of the Mechanics and Physics of Solids, 13(4), 213-222. https://doi.org/10.1016/0022-5096(65)90010-4

21. Kim, J.-M. (2004). Fully coupled poroelastic governing equations for groundwater flow and solid skeleton deformation in variably saturated true anisotropic porous geologic media. Geosciences Journal, 8(3), 291. https://doi. org/10.1007/BF02910248 
22. Levin, V. M., \& Alvarez-Tostado, J. M. (2003). Eshelby's formula for an ellipsoidal elastic inclusion in anisotropic poroelasticity and thermoelasticity. International Journal of Fracture, 119(4), L77-L82. https://doi. org/10.1023/A:1024907500335

23. Levin, V. M., \& Alvarez-Tostado, J. M. (2006). Explicit Effective Constants for an Inhomogeneous Porothermoelastic Medium. Archive of Applied Mechanics, 76(3), 199-214. https://doi.org/10.1007/s00419-006-0016-x

24. Lion, M., Skoczylas, F. \& Ledesert. B (2004). Determination of the main hydraulic and poro-elastic properties of a limestone from Bourgogne, France. International Journal of Rock Mechanics and Mining Sciences, 41(6), 915-925.

25. Madhubabu, N., Singh, P. K., Kainthola, A., Mahanta, B., Tripathy, A., \& Singh, T. N. (2016). Prediction of compressive strength and elastic modulus of carbonate rocks. Measurement, 88, 202-213. https://doi.org/10.1016/j. measurement.2016.03.050

26. Mori, T., \& Tanaka, K. (1973). Average stress in matrix and average elastic energy of materials with misfitting inclusions. Acta Metallurgica, 21(5), 571-574. https://doi.org/10.1016/0001-6160(73)90064-3

27. Nguyen, N.B. (2010). Modélisation micromécanique des roches poreuses. Application aux calcaires oolitiques [PhD Thesis]. Institut National Polytechnique de Lorraine.

28. Nguyen, N. B., Giraud, A., \& Grgic, D. (2011). A composite sphere assemblage model for porous oolitic rocks. International Journal of Rock Mechanics and Mining Sciences, 48(6), 909-921. https://doi.org/10.1016/j. ijrmms.2011.05.003

29. Nguyen, S. T., Pham, D. C., Vu, M. N., \& To, Q. D. (2016). On the effective transport properties of heterogeneous materials. International Journal of Engineering Science, 104, 75-86.

30. Nguyen, S. T., Tang, A. M., To, Q. D., \& Vu, M. N. (2019). A model to predict the elastic properties of gas hydrate-bearing sediments. Journal of Applied Geophysics, 169, 154-164.

31. Nguyen, S. T., Vu, M.-H., \& Vu, M. N. (2015). Equivalent porous medium for modeling of the elastic and the sonic properties of sandstones. Journal of Applied Geophysics, 120, 1-6. https://doi.org/10.1016/j.jappgeo. 2015.06.004

32. Nguyen, S.-T., To, Q. D., \& Vu, M. N. (2017). Extended analytical solutions for effective elastic moduli of cracked porous media. Journal of Applied Geophysics, 140, 34-41. https://doi.org/10.1016/j.jappgeo.2017.03.007

33. Nguyen, T. T. N., Vu, M. N., Tran, N. H., Dao, N. H., \& Pham, D. T. (2020). Stress induced permeability changes in brittle fractured porous rock. International Journal of Rock Mechanics and Mining Sciences, 127, 104224. https:// doi.org/10.1016/j.ijrmms.2020.104224

34. Nguyen-Sy, T., Nguyen, T.-K., Dao, V.-D., Le-Nguyen, K., Vu, N.-M., To, Q.-D., Nguyen, T.-D., \& Nguyen, T.-T. (2020). A flexible homogenization method for the effective elastic properties of cement pastes with w/c effect. Cement and Concrete Research, 134, 106106. https://doi.org/10.1016/j.cemconres.2020.106106

35. Norris, A. N. (1985). A differential scheme for the effective moduli of composites. Mechanics of Materials, 4(1), 1-16. https://doi.org/10.1016/0167-6636(85)90002-X

36. Pham, D.-T., Vu, M.-N., Trieu, H. T., Bui, T. S., \& Nguyen-Thoi, T. (2020). A thermo-mechanical meso-scale lattice model to describe the transient thermal strain and to predict the attenuation of thermo-mechanical properties at elevated temperature up to $800{ }^{\circ} \mathrm{C}$ of concrete. Fire Safety Journal, 114, 103011. https://doi.org/10.1016/j.firesaf.2020.103011

37. Nemat-Nasser, S. \& Hori, M. (1999). Micromechanics: Overall Properties of Heterogeneous Materials-2nd Edition (North Holland-Elsevier). https://www.elsevier.com/books/micromechanics-overall-properties-of-heterogeneous-materials/nemat-nasser/978-0-444-50084-7

38. Seyedi, D. M., Vu, M.-N., \& Pouya, A. (2015). A two-scale hydromechanical model for fault zones accounting for their heterogeneous structure. Computers and Geotechnics, 68, 8-16. https://doi.org/10.1016/j.compgeo.2015.03.001

39. Seyedi D, Vu MN, \& Pouya A. (2011). A Two-scale Model For Simulating the Hydromechanical Behavior of Faults During CO2 Geological Storage Operation. 45th U.S. Rock Mechanics / Geomechanics Symposium, 68, 8-16. https://www.onepetro.org/conference-paper/ARMA-11-257

40. Seyedi Darius, Armand Gilles, Conil Nathalie, Vitel Manon, \& Vu Minh-Ngoc. (n.d.). On the Thermo-Hydro-Mechanical Pressurization in Callovo-Oxfordian Claystone under Thermal Loading. Poromechanics VI, 754-761. https://doi.org/10.1061/9780784480779.093

41. Shafiro, B., Kachanov, M., Shafiro, B., \& Kachanov, M. (2000). Anisotropic effective conductivity of materials with nonrandomly oriented inclusions of diverse ellipsoidal shapes. JAP, 87(12), 8561-8569. https://doi. org/10.1063/1.373579 
42. Trieu, H.T. (2010). Laboratory and numerical investigations of variable density-flow and transport in Hele-Shaw cell. Conference: XVIII International Conference on Water Resources. Conference: XVIII International Conference on Water Resources, Barcelona. https://www.researchgate.net/publication/334544794_Laboratory_and_numerical_investigations_of_variable_density-flow_and_transport_in_Hele-Shaw_cell

43. Trieu, Hung Truong. (2011). Études théorique et expérimentale du transport de fluides miscibles en cellule HeleShaw [These de doctorat, Vandoeuvre-les-Nancy, INPL]. http://www.theses.fr/2011INPL027N.

44. Vu, M. N. (2012). Modélisation des écoulements dans des milieux poreux fracturés par la méthode des équations aux intégrales singulières [Phdthesis, Université Paris-Est]. https://pastel.archives-ouvertes.fr/pastel-00777926

45. Vu M.N, Armand G, \& Plúa C. (2019). Thermal Pressurization Coefficient of Anisotropic Elastic Porous Media Request PDF. Rock Mechanics and Rock Engineering, 53, 2027-2031.

46. Vu, M.-N., Pouya, A., \& Seyedi, D. M. (2018). Effective permeability of three-dimensional porous media containing anisotropic distributions of oriented elliptical disc-shaped fractures with uniform aperture. Advances in Water Resources, 118, 1-11. https://doi.org/10.1016/j.advwatres.2018.05.014

47. Xu, S, \& Payne, M. A. (2009). Modeling elastic properties in carbonate rocks | The Leading Edge. The Leading Edge, 28(1), 66-74

48. Hashin, Z \& Shtrikman. S. (1962). A Variational Approach to the Theory of the Effective Magnetic Permeability of Multiphase Materials: Journal of Applied Physics: Vol 33, No 10. Journal of Applied Physics, 33, 3125-3131.

49. Hashin, Z \& Shtrikman. S. (1963). A variational approach to the theory of the elastic behaviour of multiphase materials. Journal of the Mechanics and Physics of Solids, 11(2), 127-140. https://doi.org/10.1016/0022-5096(63)90060-7.

50. Zimmerman RW. (1996). Effective conductivity of a two-dimensional medium containing elliptical inhomogeneities. Proceedings of the Royal Society of London. Series A: Mathematical, Physical and Engineering Sciences, 452, 1713-1727. https://doi.org/10.1098/rspa.1996.0091.

51. Zouari, R., Benhamida, A., \& Dumontet, H. (2008). A micromechanical iterative approach for the behavior of polydispersed composites. International Journal of Solids and Structures, 45(11), 3139-3152. https://doi. org/10.1016/j.ijsolstr.2008.01.016.

\footnotetext{
Dwu-etapowa homogenizacja właściwości poroelastycznych wapienia

$W$ artykule, przedstawiono wyniki badań efektywnych właściwości poroelastycznych wapieni oolitowych w oparciu o teorię mikromechaniczną złożonego zespołu kul Hashin (CSA). Mikrostruktura wapieni oolitycznych wykazuje generalnie zbiór ziaren (oolitów) otoczonych matrycą. Ziarno i matryca sa połaczone za pośrednictwem międzyfazowej strefy przejściowej (ITZ). W tych trzech fazach materiału (oolit, ITZ i matryca) istnieja pory. Zaproponowano dwuetapowa metode homogenizacji. Pierwszy etap polega na zwiększeniu skali właściwości każdej porowatej fazy (tj. Porowatego oolitu, porowatej ITZ i porowatej matrycy), w której każda faza zawiera dwie podfazy: porową i stała. W pierwszym etapie zastosowano różnicowy schemat samouzgodnienia. Na drugim etapie trzy różne porowate składniki (oolit, ITZ i matryca) sa składane w modelu CSA. Matematyczne analogie między termosprężystością a poroelastycznościa sa wykorzystywane do uzyskania efektywnych właściwości poroelastycznych. Porównanie proponowanego modelu $z$ danymi testowymi dotyczacymi wapienia oolitycznego z Bourgogne (Francja) pomaga skalibrować parametry modelu i podkreślić role fazy ITZ.
}

Słowa kluczowe: wapień oolityczny; homogenizacja dwuetapowa; CSA; właściwości poroelastyczne; zróżnicowana spójność własna. 